\title{
Defect in Skeletal Muscle Phosphatidylinositol-3-Kinase in Obese Insulin-resistant Mice
}

\author{
Stanley J. Heydrick, Dominique Jullien, Nadine Gautier, Jean-François Tanti, Sophie Giorgetti, \\ Emmanuel Van Obberghen, and Yannick Le Marchand-Brustel \\ Institut National de la Santé et de la Recherche Médicale (INSERM) U145, Faculté de Médecine, \\ Avenue de Valombrose, 06107 Nice Cedex 02, France
}

\begin{abstract}
Activation of phosphatidylinositol-3-kinase (PI3K) is one of the earliest postreceptor events in the insulin signaling pathway. Incubation of soleus muscles from lean mice with $50 \mathrm{nM}$ insulin caused a 3-10-fold increase in antiphosphotyrosine-immunoprecipitable PI3K (antiPTyr-PI3K) activity within 2 min in muscle homogenates as well as both the cytosolic and membrane fractions. Insulin did not affect total PI3K activity. Both the antiPTyr-PI3K stimulation and activation of insulin receptor tyrosine kinase were dependent on hormone concentration. In muscles from obese, insulin-resistant mice, there was a 40$60 \%$ decrease in antiPTyr-PI3K activity after $2 \mathrm{~min}$ of insulin that was present equally in the cytosolic and membrane fractions. A significant reduction in insulin sensitivity was also observed. The defect appears to result from alterations in both insulin receptor and postreceptor signaling. Starvation of obese mice for $48 \mathrm{~h}$, which is known to reverse insulin resistance, normalized the insulin response of both PI3K and the receptor tyrosine kinase. The results demonstrate that: $(a)$ antiPTyrPI3K activity is responsive to insulin in mouse skeletal muscle, (b) both the insulin responsiveness and sensitivity of this activity are blunted in insulin-resistant muscles from obese mice, $(c)$ these alterations result from a combination of insulin receptor and postreceptor defects, and $(d)$ starvation restores normal insulin responses. (J. Clin. Invest. 1993. 91:1358-1366.) Key words: insulin • insulin resistance $\bullet$ muscle $\bullet$ obesity $\bullet$ phosphatidylinositol-3-kinase
\end{abstract}

\section{Introduction}

One of the earliest detectable events after the binding of insulin to its receptor and receptor autophosphorylation is the activation of phosphatidylinositol-3-kinase (PI3K $)^{1}(1,2)$. PI3K is a heterodimeric protein composed of an $85-\mathrm{kD}$ regulatory sub-

Address reprint requests to Dr. Yannick Le Marchand-Brustel, INSERM U145, Faculté de Medecine, Avenue de Valembrose, 06107 Nice Cedex 02, France.

Received for publication 9 June 1992 and in revised form 30 October 1992.

1. Abbreviations used in this paper: antiPTyr-PI3K, antiphosphotyrosine-immunoprecipitable phosphatidylinositol-3-kinase; GTG, goldthioglucose; IRS-1, insulin receptor substrate-1; NIDDM, non-insulin-dependent diabetes mellitus; PI, phosphatidylinositol; PI3K, phosphatidylinositol-3-kinase; PI4P, phosphatidylinositol-4-phosphate; WGA, wheat germ agglutinin

J. Clin. Invest.

(c) The American Society for Clinical Investigation, Inc.

0021-9738/93/04/1358/09 \$2.00

Volume 91, April 1993, 1358-1366 unit and a $110-\mathrm{kD}$ catalytic subunit that phosphorylates phosphatidylinositol (PI), phosphatidylinositol-4-phosphate (PI4P), and phosphatidylinositol-4,5-diphosphate on the D3 position of the inositol ring (reviewed in references 3 and 4). Both subunits are required for activity (5). Although the function of the product phosphatidylinositol-3-phosphates is not currently known, reports of PI3K association with and/or activation by a large number of oncogenes and tyrosine kinase growth factor receptors in cultured cell lines indicate that it may play a role in tyrosine kinase-mediated growth promotion $(3,4)$. Indeed, ligand-mediated tyrosine kinase stimulation appears to be essential for PI3K activation by receptor tyrosine kinases (6-9). With regard to the insulin receptor, the bulk of the recent studies have led to the suggestion that the insulin receptor tyrosine kinase first phosphorylates insulin receptor substrate-1 (IRS1), the $170-185-\mathrm{kD}$ protein which is its primary substrate in vivo, and that the tyrosine phosphorylated form of IRS-1 then acts as a ligand to activate PI3K via an interaction with src homology regions in the $85-\mathrm{kD}$ subunit (10-12).

Two groups have recently demonstrated that insulin-responsive PI3K exists in an important insulin target cell, the adipocyte $(13,14)$. Both antiphosphotyrosine immunoprecipitable $(13,14)$ and anti-85-kD subunit immunoprecipitable (14) PI3K activities were stimulated severalfold by insulin; this response was attenuated by physiological insulin antagonists $(13,14)$. As in cultured cell studies, there was a strong correlation between the insulin-stimulated and antagonist-attenuated PI3K activity with changes in insulin receptor tyrosine kinase activity (14). In that insulin's effect on adipocytes is metabolic rather than growth promoting, PI3K activation is not associated solely with cell division.

Skeletal muscle, by virtue of its mass, plays a primary role in the body's metabolic response to insulin. For example, in humans it accounts for most of the whole body insulin-stimulated glucose uptake $(15,16)$. Despite the physiological importance of muscle, nothing is known of the role of PI3K in this tissue. This question is especially relevant in pathophysiological states where there is skeletal muscle insulin resistance. One such pathophysiological state is the obese, hyperinsulinemic syndrome that is commonly associated with non-insulin-dependent diabetes mellitus (NIDDM). Experimentally, this insulin-resistant state can be obtained in mice by the administration of goldthioglucose (GTG) $(17,18)$. At the cellular level, GTG-induced skeletal muscle insulin resistance is associated with both insulin receptor and intracellular defects, including a decrease in receptor number and an alteration in the receptor kinase (19) as well as a blunted insulin-stimulation of glucose transport and a number of metabolic pathways (18, 20, 21 ). To evaluate the potential role of PI3K in skeletal muscle insulin signaling, we used the isolated soleus muscle to investigate two questions. First, what are the characteristics of PI3K activation by insulin, and, second, are any of the foregoing characteristics altered in insulin-resistant obese mice? 


\section{Methods}

Animals. Male Swiss-Albino mice (Iffa-Credo, Lyon, France) having access to food and water ad libitum served as muscle donors. Obesity was induced in some mice by a double injection of goldthioglucose at 3 wk of age as described previously (18). Mice were 6-8 mo old at the time of the experiments. When indicated, mice were starved for $48 \mathrm{~h}$ with free access to water.

Materials. Methylamine free base was purchased from Aldrich Chemical Co., (Milwaukee, WI), and bovine serum albumin (fraction V) from Euromedex (Strasbourg, France). PI (reference no. P2517) was obtained from Sigma Chemical Co. (St. Louis, MO), phosphatidylserine from Serva (Heidelberg, FRG). $\left[{ }^{32} \mathrm{P}\right]$ ATP was purchased from ICN; all other radioactive compounds were purchased from Amersham International (Bucks, UK). Plastic-backed Silica Gel 60 TLC plates were purchased from Merck (Darmstadt, FRG), and wheat germ agglutinin agarose from Biomakor (reference no. 8818-1). Light petroleum ether was bought from Fluka (Buchs, Switzerland). All other chemical and biochemical products were from Sigma or Merck.

Muscle incubations. Mouse soleus muscles were incubated as described previously (18). Briefly, mice were killed by cervical dislocation and solei were surgically removed and tied via their tendons to stainless steel clips. Muscles were preincubated for $15 \mathrm{~min}$ in $1.0 \mathrm{ml}$ of Krebs-Ringer bicarbonate buffer, $\mathrm{pH} 7.3$, supplemented with $1 \%$ bovine serum albumin and $2 \mathrm{mM}$ pyruvate. They were then incubated (2-60 $\mathrm{min}$ ) in a second flask containing $1.0 \mathrm{ml}$ of the same buffer with additions as indicated. All incubations were carried out at $37^{\circ} \mathrm{C}$ under an atmosphere of $95 \% \mathrm{O}_{2}: 5 \% \mathrm{CO}_{2}$. After incubation, muscles were rapidly blotted and homogenized by sonification with a VibraCell ultrasonic sonifier (Sonics and Materials, Inc., Danbury, CT) for $5 \mathrm{~s}$ at $70 \%$ full power.

Determination of PI3K activity in immunoprecipitates. Muscles were homogenized in $0.5 \mathrm{ml}$ of lysis buffer $(140 \mathrm{mM} \mathrm{NaCl}, 10 \mathrm{mM}$ Tris- $\mathrm{HCl}$, pH 8.1, $1 \mathrm{mM} \mathrm{CaCl}_{2}, 1 \mathrm{mM} \mathrm{MgCl} 2,10 \%$ glycerol, $1 \%$ Nonidet P-40 (NP-40), $10 \mu \mathrm{g} / \mathrm{ml}$ aprotinin, $50 \mu \mathrm{M}$ leupeptin, $200 \mu \mathrm{M}$ ammonium vanadate, $1 \mathrm{mM}$ PMSF, and solubilization was achieved by continuous stirring for $1 \mathrm{~h}$ at $4^{\circ} \mathrm{C}$. The homogenates were then subjected to centrifugation at $12,000 \mathrm{~g}$ for $4 \mathrm{~min}$ and the supernatants were used for protein determination and immunoprecipitation with affinitypurified sheep antiphosphotyrosine antibodies (22). Before immunoprecipitation, the antibody ( $20 \mu \mathrm{g}$ per sample $)$ was preadsorbed to protein-G-sepharose ( $20 \mu \mathrm{l}$ of hydrated beads per sample) by incubation for $30 \mathrm{~min}$ at room temperature. The beads were washed twice with PBS/ $1 \%$ Nonidet P-40 and then immunoprecipitation was initiated by the addition of $400 \mu$ l of homogenate. The homogenate-bead suspensions were agitated for an additional $1.5 \mathrm{~h}$ at $4^{\circ} \mathrm{C}$, and the beads were pelleted, washed thrice with PBS/1\% Nonidet P-40/200 $\mu \mathrm{M}$ ammonium vanadate, and twice with $0.5 \mathrm{M} \mathrm{LiCl} / 10 \mathrm{mM}$ Hepes ( $\mathrm{pH} 7.4$ )/ $200 \mu \mathrm{M}$ ammonium vanadate, and twice with $10 \mathrm{mM}$ Tris- $\mathrm{HCl}, \mathrm{pH}$ $7.4 / 100 \mathrm{mM} \mathrm{NaCl} / 1 \mathrm{mM}$ EDTA/200 $\mu \mathrm{M}$ ammonium vanadate. PI3K was assayed directly on the protein-G-Sepharose-immunoprecipitate complex as described previously (23). $5 \mu \mathrm{l}$ of a sonicated mixture of PI ( $10 \mu \mathrm{g})$ and phosphatidylserine $(2.5 \mu \mathrm{g})$ in $10 \mathrm{mM}$ Hepes, $1 \mathrm{mM}$ EGTA, pH 7.5 were added to the beads and the reaction was initiated by the addition of $25 \mu \mathrm{l}$ of a reaction mixture consisting of $40 \mathrm{mM}$ Hepes, $\mathrm{pH} 7.4 / 20 \mathrm{mM} \mathrm{MgCl}_{2} / 50 \mu \mathrm{M}\left[\gamma^{32} \mathrm{P}\right] \mathrm{ATP}(30 \mu \mathrm{Ci})$. The reaction was stopped after $20 \mathrm{~min}$ at $25^{\circ} \mathrm{C}$ and the phospholipids were extracted into chloroform by the sequential addition of $40 \mu \mathrm{l} 4 \mathrm{~N} \mathrm{HCl}$ and $160 \mu \mathrm{l}$ chloroform:methanol $(1: 1, \mathrm{vol} / \mathrm{vol})$. The extracted lipids were spotted onto silica gel 60 TLC plates precoated with potassium oxalate ( $1 \%$ potassium oxalate, 2 mM EDTA, pH 7.0/methanol; 3:2). After autoradiography, the band corresponding to phosphatidylinositol-3-phosphate (PI3P) was excised and its radioactivity was quantitated by liquid scintillation counting.

PI3K was assayed in anti-p85 immunoprecipitates essentially as described (14). $1 \mu \mathrm{l}$ of a serum containing antibody raised against a peptide corresponding to amino acids 513-531 of the 85-kD PI3K subunit (Ab 51, kindly donated by J. Schlessinger, New York University, New York) was preadsorbed to $10 \mu$ l of hydrated protein-A-Seph- arose. The beads were washed and then incubated for $2 \mathrm{~h}$ at $4^{\circ} \mathrm{C}$ with $15 \mu \mathrm{l}$ of membrane or cytosolic fraction. PI3K associated with the beads was assayed as for antiPTyr immunoprecipitates.

In experiments where homogenates were fractionated into particulate and cytosolic fractions, homogenization was carried out in the absence of NP-40. After centrifugation for $1 \mathrm{~h}$ at $100,000 \mathrm{~g}\left(4^{\circ} \mathrm{C}\right)$, the $\mathrm{NP}-40$ was added to the supernatant (cytosolic fraction) to give a final concentration of $1 \%$ and the pellet (particulate fraction) was resuspended by sonification in homogenization buffer containing $1 \%$ NP40. After solubilization for $1 \mathrm{~h}$ at $4^{\circ} \mathrm{C}$, the analysis of antiphosphotyrosine and anti-p85 immunoprecipitable PI3K activity was carried out as described above.

HPLC analysis of deacylated lipids. Phospholipids were deacylated as described previously (24). After TLC and autoradiography, the lipid band co-migrating with phosphatidylinositol phosphate was cut from the TLC plate and deacylated by incubation with methylamine reagent $(42.8 \%$ of $25 \%$ methylamine free base in water, $45.7 \%$ methanol, $11.4 \%$ $n$-butanol) for $50 \mathrm{~min}$ at $53^{\circ} \mathrm{C}$. The samples were dried in vacuo, resuspended in water, and washed twice with an equal volume of $n$-butanol:light (low boiling) petroleum ether:ethyl formate (20:4:1 $\mathrm{vol} / \mathrm{vol}$ ), and dried again. Anion exchange HPLC analysis of the deacylated lipids was carried out with a dual-pump system (Kontron Instruments, St. Quentin en Yvelines, France) using a Partisphere-SAX column (Whatman Scientific, Ltd., Maidstone, UK) $(23,25)$. Solvent A was water and solvent $\mathrm{B}$ was $1 \mathrm{M}\left(\mathrm{NH}_{4}\right)_{2} \mathrm{PO}_{4}, \mathrm{pH}$ 3.8. In the analysis protocol, samples were introduced into the system under isocratic conditions ( $100 \% \mathrm{~A}$ for $5 \mathrm{~min}$ ) and then a linear gradient from $0 \%$ to $18 \%$ $B$ was developed over $60 \mathrm{~min}$. The retention time of glycerophosphoinositol-4-phosphate was determined using a deacylated [ $\left.{ }^{3} \mathrm{H}\right] \mathrm{PI} 4 \mathrm{P}$ standard.

Determination of insulin receptor tyrosine kinase activity and autophosphorylation. Insulin receptor tyrosine kinase activity was assayed in partially purified insulin receptor preparations (26). Muscles were homogenized by sonification in $0.5 \mathrm{ml}$ of solubilization buffer $(50 \mathrm{mM}$ Hepes, $150 \mathrm{mM} \mathrm{NaCl}, 10 \mathrm{mM}$ EDTA, $10 \mathrm{mM}$ sodium pyrophosphate, $100 \mathrm{mM} \mathrm{NaF}, 2 \mathrm{mM}$ ammonium vanadate, $30 \mathrm{mM}$ PNPP, $1 \mathrm{mM}$ PMSF, $10 \mu \mathrm{g} / \mathrm{ml}$ aprotinin, $50 \mu \mathrm{M}$ leupeptin, $1 \%$ Triton $\mathrm{X}-100, \mathrm{pH}$ 7.4 ), and solubilization was allowed for $30 \mathrm{~min}$ at $4^{\circ} \mathrm{C}$. The samples were centrifuged for $15 \mathrm{~min}$ at $10,000 \mathrm{~g}$, aliquots of the resulting supernatants (usually $250-400 \mu$ ) were added to $50 \mu \mathrm{l}$ of wheat germ agglutinin agarose (WGA, preequilibrated with solubilization buffer), and the resulting suspensions were gently agitated for $1 \mathrm{~h}$ at $4^{\circ} \mathrm{C}$. After one wash with the solubilization buffer $/ 0.1 \%$ Triton $\mathrm{X}-100$ and two washes with assay buffer ( $30 \mathrm{mM}$ Hepes, pH $7.4,30 \mathrm{mM} \mathrm{NaCl}, 30 \mathrm{mM}$ bis-(paranitrophenyl) phosphate (PNPP), and $0.1 \%$ Triton X-100), WGA-bound glycoproteins were eluted from the beads by the addition of 200-300 $\mu$ l of $0.3 \mathrm{M} \mathrm{N}$-acetylglucosamine/assay buffer. After 30 min at $4^{\circ} \mathrm{C}$, the eluate/bead mixtures were centrifuged at $10,000 \mathrm{~g}$ for 5 min and the resulting supernatants, containing partially purified insulin receptors, were immediately used in the insulin receptor tyrosine kinase assay. $10 \mu \mathrm{l}$ of $1.5 \mathrm{mg} / \mathrm{ml}$ poly (glutamate:tyrosine, $4: 1$ ) was added to a 40- $\mu$ l aliquot of eluate and the kinase reaction was initiated via the addition of $10 \mu \mathrm{l}$ of ATP $\operatorname{mix}\left(2 \mu \mathrm{M}\left[\gamma^{32} \mathrm{P}\right] \mathrm{ATP}, 2.5 \mu \mathrm{Ci}, 4 \mathrm{mM}\right.$ $\mathrm{MnCl}_{2}, 8 \mathrm{mM} \mathrm{MgCl}_{2}$, final concentrations). Tyrosine phosphorylation was allowed to procede for $30 \mathrm{~min}$ at room temperature. To stop the reaction, $45-50 \mu$ l of the reaction mixture was spotted onto $2 \times 2$ $\mathrm{cm}$ Whatman ET 31 filter paper squares and the papers were placed in a $10 \%$ TCA bath containing $10 \mathrm{mM}$ sodium pyrophosphate. The papers were washed extensively with $5 \% \mathrm{TCA} / 10 \mathrm{mM}$ sodium pyrophosphate and dried; radioactivity incorporated into the substrate was quantitated by Cerenkov counting.

Activation of PI3K in vitro. PI3K was activated in vitro by incubating muscle homogenates with purified insulin receptors (27). Human insulin receptors were partially purified from NHIR-3T3 cells using a WGA Sepharose affinity column. On the day of the experiment, $4 \mu \mathrm{l}$ of hydrated protein-A-Sepharose beads per sample were incubated with appropriate amounts of receptor preparation and monoclonal antibodies to human insulin receptors for $2 \mathrm{~h}$ at $4^{\circ} \mathrm{C}$. These antibodies had no cross-reactivity with mouse insulin receptors. The beads were washed 
with a buffer containing $30 \mathrm{mM}$ Hepes, $30 \mathrm{mM} \mathrm{NaCl}$, and $200 \mu \mathrm{M}$ ammonium vanadate (HN). Protein-A-bound receptors were activated by incubation for $45 \mathrm{~min}$ at room temperature with $100 \mathrm{nM}$ insulin in $\mathrm{HN}$ containing $30 \mu \mathrm{M}$ ATP, $10 \mathrm{mM} \mathrm{MgCl}_{2}, 5 \mathrm{mM} \mathrm{MnCl}$, and $1 \%$ BSA. Nonactivated receptors were incubated with the same mixture containing $200 \mathrm{mM}$ EDTA. After receptor activation, the beads were washed once with HN. PI3K was then activated in vitro by incubating the activated receptors with $150 \mu \mathrm{l}$ of muscle "cytosol" for 5-7 min at room temperature. "Cytosol" was prepared from homogenates of muscles incubated for $15 \mathrm{~min}$ in Krebs-Ringer bicarbonate buffer, $2 \mathrm{mM}$ pyruvate, $1 \%$ BSA as described above. Homogenization was carried out in $300 \mu$ l of PI3K lysis buffer. After solubilization for 1 $\mathrm{h}$ at $4^{\circ} \mathrm{C}$, homogenates were centrifuged for $5 \mathrm{~min}$ at $10,000 \mathrm{~g}\left(4^{\circ} \mathrm{C}\right)$ and the supernatant ("cytosol") removed. Cytosol was supplemented with $30 \mu \mathrm{M}$ ATP, $10 \mathrm{mM} \mathrm{MgCl}$, and $5 \mathrm{mM} \mathrm{MnCl}_{2}$ (final concentrations) before incubation with insulin receptors. The PI3K activation was stopped by the addition of $10 \mu \mathrm{l}$ of $1 \mathrm{M}$ EDTA. The protein-A beads, containing the previously bound insulin receptors and newly associated proteins, were washed and their associated PI3K activity was determined as in immunoprecipitates. Control incubations were performed with insulin receptors alone and with cytosol alone.

Glucose transport. Soleus muscle glucose transport was determined from the uptake of $\left[{ }^{3} \mathrm{H}\right] 2$-deoxyglucose (final: $0.1 \mathrm{mM}, 0.5 \mu \mathrm{Ci} / \mathrm{ml}$ ) during 10 min of incubation as described previously (18). A correction for extracellular 2-deoxyglucose was made using $\left[{ }^{14} \mathrm{C}\right]$ sucrose (final $0.1 \mu \mathrm{Ci} / \mathrm{ml}$ ) as a marker. Glucose transport was measured in parallel with either PI3K or insulin receptor tyrosine kinase activity by scintillation counting of the post-protein-A-Sepharose or WGA supernatants.

Glucose and insulin determinations. Blood was withdrawn from the inferior vena cava before the muscle surgery. After a brief centrifugation to sediment cellular elements, the plasma was drawn off and stored at $-20^{\circ} \mathrm{C}$ until further analysis. Plasma glucose was assayed via glucose oxidase and plasma insulin was determined by radioimmunoassay (18).

Protein determination. Proteins were determined in muscle homogenates using the Bio-Rad Protein Assay (Bio-Rad Laboratories, Richmond, CA ). Crystalline bovine serum albumin was used as a standard.

\section{Results}

Characteristics of the insulin stimulation of PI3K in skeletal muscle. To determine if insulin-responsive PI3K exists in skeletal muscle, soleus muscles were incubated for varying lengths of time with $50 \mathrm{nM}$ insulin, a concentration that is maximally effective in stimulating glucose transport. After homogenization, phosphatidylinositol kinase activity (PIK) was assessed in antiphosphotyrosine immunoprecipitates. As shown in Fig. 1, insulin induced a severalfold stimulation of a PI kinase giving a product that co-migrated with PIP in TLC separations; HPLC analysis of this band indicated that it had a retention time equivalent to that of PI3P(24). Antiphosphotyrosine-immunoprecipitable-PI3K activity (antiPTyr-PI3K) was maximally stimulated within $2 \mathrm{~min}$ of exposure to $50 \mathrm{nM}$ insulin; thereafter it declined over the next 20-30 min and then plateaued, although at no time did it return to basal levels (Fig. 2). Thus the response of antiPTyr-PI3K to $50 \mathrm{nM}$ insulin is characterized by a rapid initial activation followed by a partial deactivation. In the presence of a more physiological insulin concentration, $2 \mathrm{nM}$, the stimulation of antiPTyr-PI3K activity was both smaller and slower, with activity peaking after $30 \mathrm{~min}$ and then returning to basal by $60 \mathrm{~min}$ (data not shown). The antiPTyrPI3K response to various insulin concentrations was measured in solei incubated for $2 \mathrm{~min}$ (Fig. 3). A stimulation of antiPTyr-PI3K was evident at $2 \mathrm{nM}$ insulin, and progressively larger stimulations were observed as the insulin concentration increased to $50 \mathrm{nM}$. Insulin had no effect on the PI3K activity

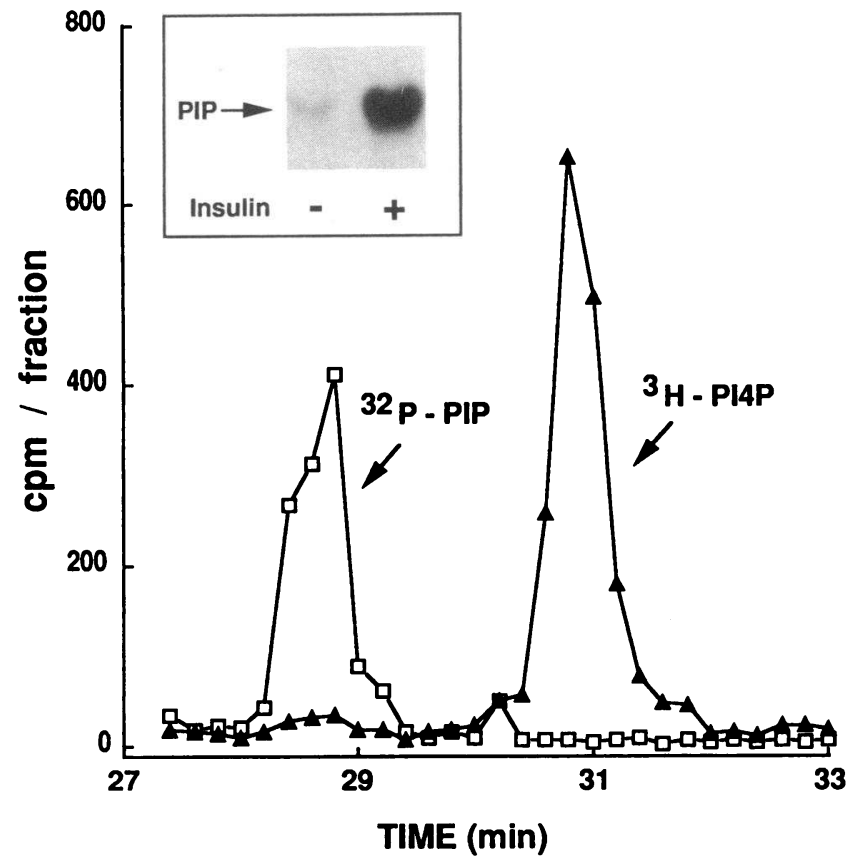

Figure 1. HPLC separation of PIPs. Muscles were incubated for $2 \mathrm{~min}$ without and with $50 \mathrm{nM}$ insulin and PI-kinase was assayed in homogenate antiphosphotyrosine immunoprecipitates by the addition of PI and $\left[{ }^{32} \mathrm{P}\right] \mathrm{ATP}$ as described in the methods. The ${ }^{32} \mathrm{P}$-lipid band co-migrating with PIP in TLC chromatograms (inset) was deacylated as described in the methods. The ${ }^{32} \mathrm{P}$-deacylated product and a likewise deacylated $\left[{ }^{3} \mathrm{H}\right] \mathrm{PI} 4 \mathrm{P}$ standard were mixed and introduced into the HPLC system, and the chromatogram was developed as described in the methods. The depicted chromatogram is an analysis from a muscle stimulated by insulin; the PIP band from unstimulated muscles had an identical composition.

immunoprecipitated by an antibody to the $85-\mathrm{kD}$ subunit (anti-p85-immunoprecipitable, refer to Table II).

Insulin receptor tyrosine kinase activation in soleus muscles. To determine if a relationship exists between the activation of PI3K and insulin receptor tyrosine kinase in skeletal muscle, incubated soleus muscles were exposed to $50 \mathrm{nM}$ insulin for varying lengths of time and their insulin receptor kinase activity was measured in homogenates made under conditions giving a maximal preservation of the receptor phosphorylation state. Fig. 4 shows that there is a significant stimulation of insulin receptor tyrosine kinase activity within 2 min of incubation, although, unlike the initial stimulation of PI3K activity, maximal activity was not achieved until after $30 \mathrm{~min}$. The receptor kinase activation time course closely paralleled that of receptor autophosphorylation as shown in the antiphosphotyrosine Western blot in the inset to Fig. 4. Muscle incubations carried out with $2 \mathrm{nM}$ insulin resulted in a much smaller but still significant receptor kinase stimulation that also peaked at 30 min (data not shown). To establish the sensitivity of the insulin receptor tyrosine kinase to insulin, muscles were incubated for $10 \mathrm{~min}$ with insulin concentrations varying from 0 to $50 \mathrm{nM}$. As seen in Fig. 5, there was an increasing stimulation of receptor kinase activity as the insulin concentration was raised from 0.5 to $50 \mathrm{nM}$ that was coincident with the activation of antiPTyr-PI3K activity after 2 min of insulin exposure, but was rightward shifted compared to that of glucose transport.

Response of PI3K to insulin is defective in muscles from obese mice. Since the foregoing data suggested a link between 


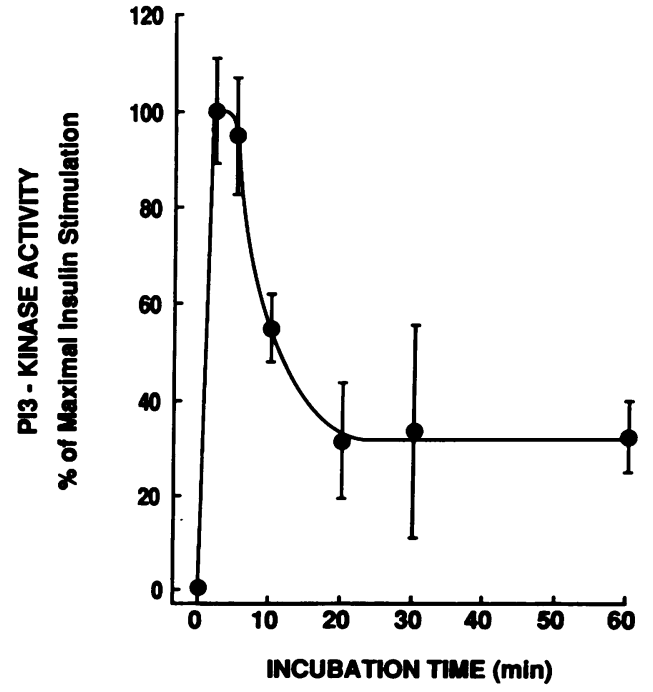

Figure 2. Time course of insulin-stimulation of PI3K activity in incubated soleus muscles. Muscles were incubated in the presence of $50 \mathrm{nM}$ insulin for 2-60 min and PI3K was assayed in antiphosphotyrosine immunoprecipitates as described in the legend to Fig. 1 and under Methods. Plotted points represent the percentage of the $50 \mathrm{nM}$ insulin stimulation of PI3K activity at 2 min (i.e., insulin minus basal). The maximal activity represents a threefold stimulation over the basal ( 0 insulin) activity, which did not change over $60 \mathrm{~min}$. In these experiments, the radioactivity incorporated into PI3P in muscles incubated with insulin for $2 \mathrm{~min}$ was ranged from 300 to $600 \mathrm{cpm} / \mathrm{mg}$ protein; $\sim 1 \mathrm{mg}$ of homogenate protein was assayed. Results are expressed as the mean \pm SEM from determinations in 4-10 muscles.

PI3K stimulation and the activation of the insulin receptor tyrosine kinase, we examined insulin-mediated PI3K stimulation in insulin-resistant muscles having abnormal receptor tyrosine kinase activation. The GTG-obese mice used in the present study were characterized by a eightfold increase in plasma

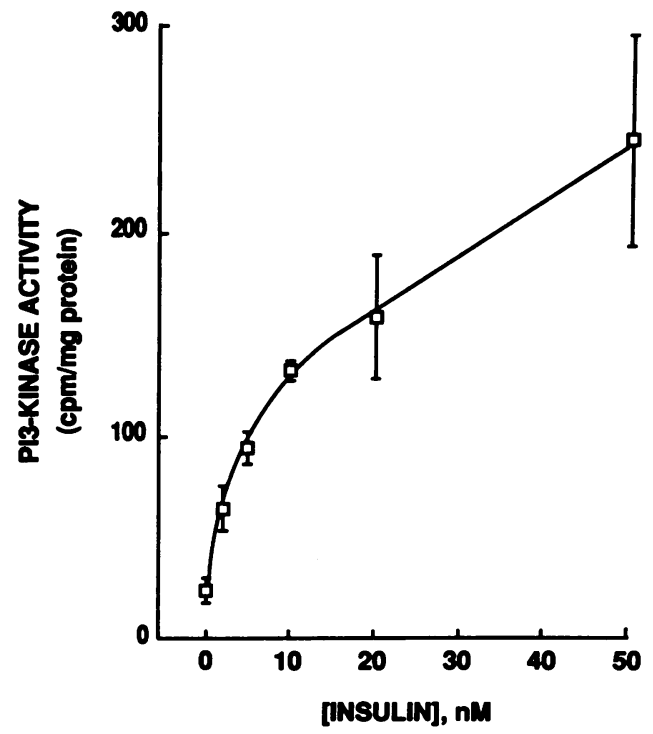

Figure 3. Dose-response curve for PI3K activation by insulin in incubated soleus muscles. Solei were incubated for $2 \mathrm{~min}$ in the presence of the indicated insulin concentrations and PI3K was assayed in antiPTyr immunoprecipitates as in Fig. 1. Results are expressed as means $\pm \operatorname{SEM}(n=4)$.

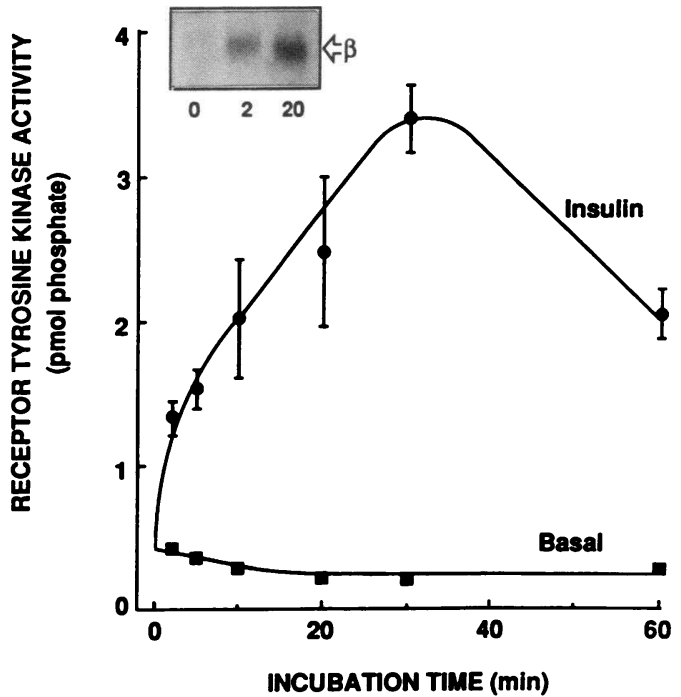

Figure 4. Time course of insulin-stimulation of its receptor tyrosine kinase in incubated soleus muscles. Muscles were incubated without (basal) or with $50 \mathrm{nM}$ insulin for up to $60 \mathrm{~min}$. After homogenization, insulin receptors were partially purified by WGA chromatography and incubated with [ $\left.{ }^{32} \mathrm{P}\right]$ ATP and poly-(Glu:Tyr) to assay tyrosine kinase activity. Points represent the picomoles phosphate incorporated into poly-(Glu:Tyr) per milligram of muscle protein. Results are expressed as means from two muscles (basal) or means \pm SEM from three muscles (insulin). The variation in the points composed of two values did not exceed $15 \%$ of the mean. The inset shows an antiphosphotyrosine western blot made on an antiphosphotyrosine immunoprecipitate from the homogenates ( $\beta$, insulin receptor $\beta$-subunit).

insulin and a slight elevation in plasma glucose (Table I). Their skeletal muscle was characterized by a $48 \%$ decrease in the stimulation of glucose transport by insulin (Table I).

To determine if the obese-hyperinsulinemic syndrome is associated with a defect in PI3K activation, soleus muscles from obese, insulin resistant mice and age-matched controls were incubated for up to $20 \mathrm{~min}$ in the presence of $50 \mathrm{nM}$ insulin. As seen in Fig. $6 \mathrm{~A}$, the maximal ( $2 \mathrm{~min}$ ) activation of antiPTyr-PI3K by insulin was clearly blunted in incubated muscles from obese animals and this defect was still evident after $20 \mathrm{~min}$ of insulin exposure. In insulin dose-response experiments performed at $2 \mathrm{~min}$ insulin exposure, antiPTyrPI3K in muscles from obese animals was also less sensitive to insulin, as demonstrated in Fig. $6 \mathrm{~B}$ by a marked rightward shift in its activation curve. Thus the obesity-associated defect in PI3K activation results in pronounced alterations in both insulin response and sensitivity.

To explore the possibility that the alteration in PI3K activity in muscles from obese mice is associated with a diminished ability of PI3K to associate with membranes, antiPTyr- and anti-p85-immunoprecipitable PI3K activities were assayed in muscle cytosolic and particulate fractions after exposure to insulin. In homogenates from lean muscles, an insulin-mediated stimulation of antiPTyr-PI3K activity was observed in both fractions ( Table II). However, the antiPTyr-PI3K expressed as a percent of the total (anti-p85) PI3K activity was two- to threefold higher in the particulate fraction. There was no insulin-induced change in either the total anti-p85-PI3K activity or that associated with the particulate fraction. In muscle homogenates from obese animals, the insulin-stimulated increases in 


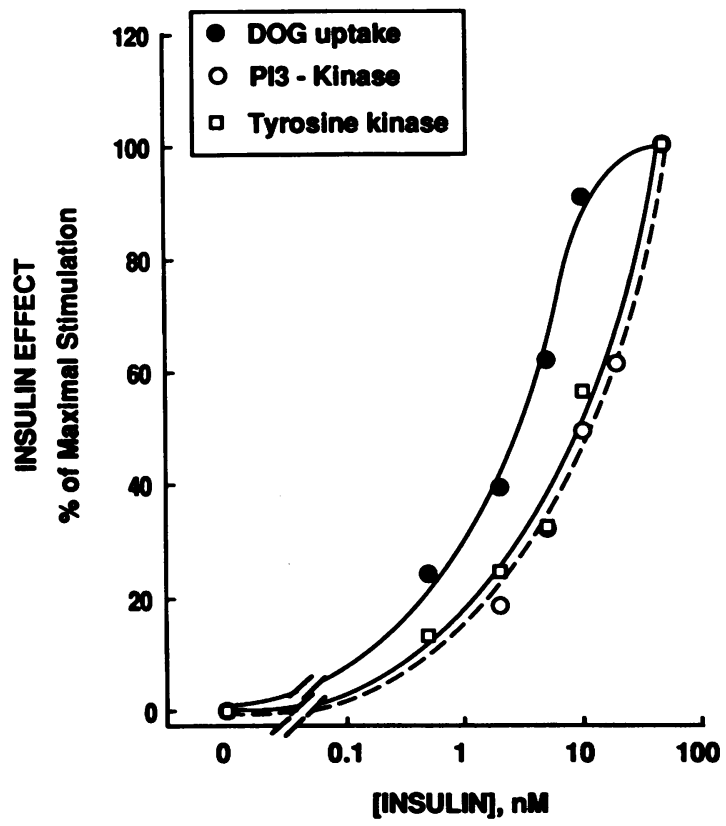

Figure 5. Comparison of the dose responses of the activation of PI3-kinase, IR tyrosine kinase, and glucose transport by insulin. Soleus muscles were incubated for 2 min (antiPTyr-PI3K, see legend to Fig. 1) or $10 \mathrm{~min}$ (insulin receptor tyrosine kinase, see legend to Fig. 4) with the indicated insulin concentrations. Glucose uptake was assessed from the uptake of $\left[{ }^{3} \mathrm{H}\right] 2$-deoxyglucose by the muscles in which receptor kinase activity was measured; the PI3K activation curve was taken from Fig. 3. Points represent means from four muscles.

cytosolic and particulate antiPTyr-PI3K activity were diminished by $50-70 \%$. In contrast, obesity had little effect on the total anti-p85-PI3K activity or in the percentage that was membrane-associated. Thus the defect is not related to a de-

Table I. Characteristics of Animals and Muscles

\begin{tabular}{lrrr}
\hline & Lean mice & Fed obese & Fasted obese \\
\hline Animals & & & \\
$\quad$ Body weight $(g)$ & $45.6 \pm 0.8$ & $66.5 \pm 1.4^{*}$ & $55.5 \pm 1.3^{* *}$ \\
Plasma glucose $(\mathrm{mM})$ & $11.1 \pm 0.3$ & $13.3 \pm 0.4^{*}$ & $6.7 \pm 0.4^{* *}$ \\
$\quad$ Plasma insulin $(\mathrm{ng} / \mathrm{ml})$ & $1.7 \pm 0.2$ & $13.6 \pm 2.9^{*}$ & $0.7 \pm 0.1^{* *}$ \\
Muscle & & & \\
$\quad$ Protein $(\mathrm{mg} / \mathrm{muscle})$ & $1.44 \pm 0.03$ & $1.46 \pm 0.03$ & $1.50 \pm 0.04$ \\
$\quad$ Deoxyglucose uptake & & & \\
$\quad \quad$ (nmol/mg & & & \\
$\quad$ protein per $10 \mathrm{~min})$ & & & \\
$\quad$ Basal & $0.35 \pm 0.04$ & $0.34 \pm 0.04$ & \\
$\quad$ Insulin & $0.93 \pm 0.03$ & $0.64 \pm 0.09^{*}$ & \\
& & & \\
\hline
\end{tabular}

Fed lean, fed obese, and fasted obese mice were used at 20-30 wk of age. Glycemia and insulinemia were determined as described in methods. Soleus muscles were isolated and deoxyglucose uptake was measured at the end of a 10-min incubation in the presence of 2$\left[{ }^{3} \mathrm{H}\right] \mathrm{DOG}$ as described in methods. Results are presented as means \pm SEM of 20 values for lean and fed obese mice, and 10 values for starved obese mice, or of 12 muscles for DOG uptake. * Values different from lean mice with $P<0.005$. ${ }^{\ddagger}$ Values different from fed obese with $P<0.01$.
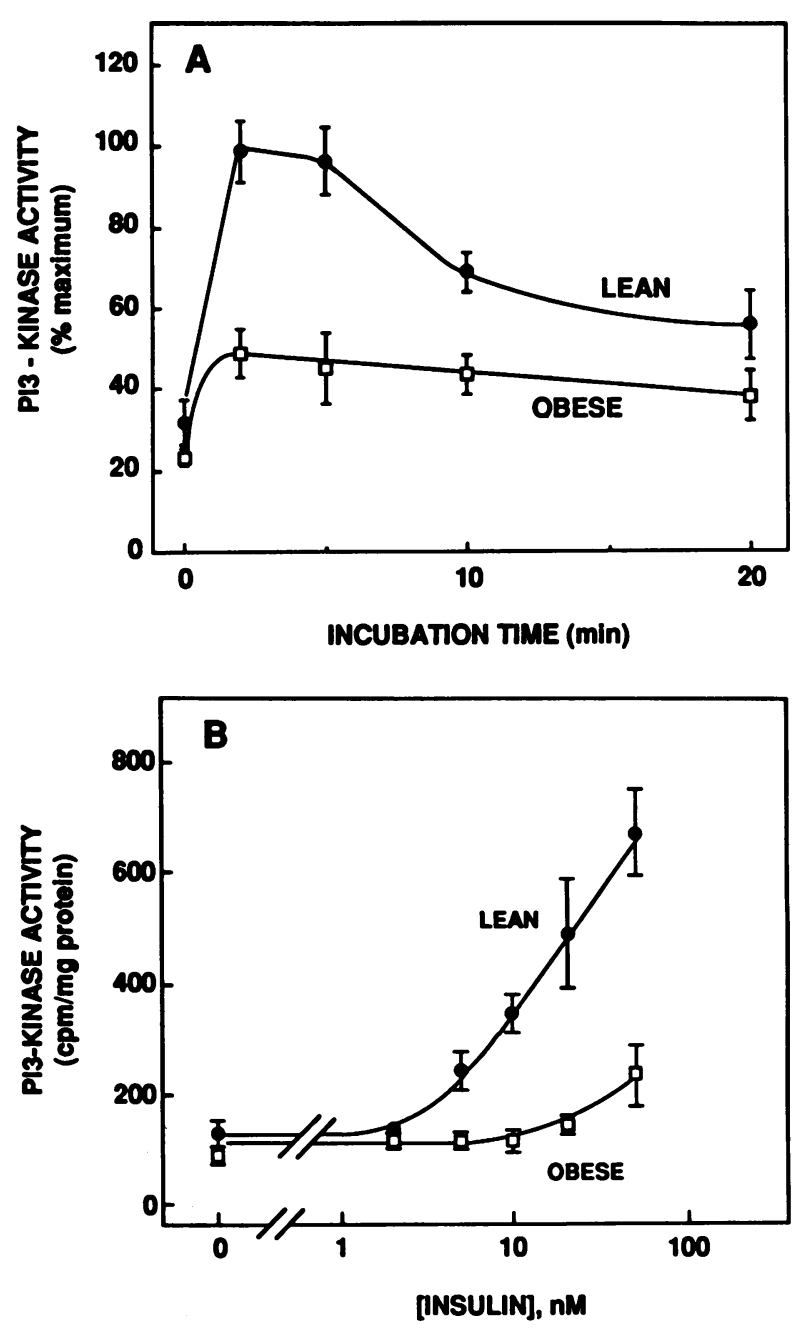

Figure 6. Effects of obesity on insulin-stimulated PI3K activity in the incubated soleus muscle: time course and dose response. $(A)$ Solei from lean and obese mice were incubated in parallel with $50 \mathrm{nM}$ insulin for the indicated times and antiPTyr-PI3K activity was assayed as described in the legend to Fig. 1. The antiPTyr-PI3K activity in lean muscles incubated for 2 min with insulin was defined as $100 \%$. All results were expressed as means $\pm \operatorname{SEM}(n=4-10)$. (B) Muscles were incubated for $2 \mathrm{~min}$ in the presence of various insulin concentrations and antiPTyr-PI3K activity was determined as in Fig. 1. Points represent means $\pm \operatorname{SEM}(n=4-11)$.

crease in PI3K activity per se, but rather in the processes that bring about its activation.

Obesity-associated receptor defects. Obesity had previously been shown to be associated with a defective activation of the insulin receptor tyrosine kinase when insulin receptors were partially purified from skeletal muscle homogenates and then incubated with insulin (19). Thus the defective stimulation of PI3K by insulin could result at least in part from an alteration in the activation of the receptor tyrosine kinase in the intact muscle. To test this proposal, muscles from lean and insulin-resistant obese animals were incubated for $10 \mathrm{~min}$ in the absence (basal) and presence of $50 \mathrm{nM}$ insulin, and their insulin receptor tyrosine kinase activity was measured in partially purified insulin receptor preparations made under conditions giving a maximal preservation of protein phosphorylation. Fig. 7 shows 
Table II. Measurement of PI3K in Cytosolic and Membrane Fractions in Muscles of Lean and Obese Mice

\begin{tabular}{|c|c|c|c|c|c|c|}
\hline \multirow[b]{2}{*}{ Incubation time ( $\mathrm{min}$ ) } & \multicolumn{3}{|c|}{ Lean mice } & \multicolumn{3}{|c|}{ Obese mice } \\
\hline & 0 & 2 & 10 & 0 & 2 & 10 \\
\hline \multicolumn{7}{|l|}{ Anti-p85-PI3K } \\
\hline Total $\left(\mathrm{cpm} \times 10^{-3} / \mathrm{mg}\right)$ & $68.6 \pm 8.5$ & $50.7 \pm 7.5$ & $56.6 \pm 9.9$ & $74.6 \pm 11.8$ & $83.0 \pm 16.2$ & $64.6 \pm 6.9$ \\
\hline Membrane (\% total) & $23.0 \pm 3.9$ & $22.4 \pm 2.3$ & $28.0 \pm 3.1$ & $18.0 \pm 2.3$ & $17.5 \pm 3.1$ & $22.8 \pm 4.2$ \\
\hline \multicolumn{7}{|l|}{ AntiPTyr-PI3K } \\
\hline \multicolumn{7}{|l|}{ Cytosolic } \\
\hline $\mathrm{cpm} / \mathrm{mg}$ & $168 \pm 57$ & $702 \pm 200$ & $499 \pm 166$ & $97 \pm 25$ & $274 \pm 60^{*}$ & $229 \pm 65^{*}$ \\
\hline Percentage of $\mathrm{p} 85$ & $0.20 \pm 0.04$ & $0.93 \pm 0.31$ & $0.44 \pm 0.09$ & $0.12 \pm 0.04$ & $0.30 \pm 0.05^{\ddagger}$ & $0.29 \pm 0.06$ \\
\hline \multicolumn{7}{|l|}{ Membrane } \\
\hline $\mathrm{cpm} / \mathrm{mg}$ & $174 \pm 27$ & $502 \pm 109$ & $470 \pm 115$ & $108 \pm 20$ & $282 \pm 51^{*}$ & $212 \pm 38^{*}$ \\
\hline Percentage of $\mathrm{p} 85$ & $0.60 \pm 0.13$ & $2.00 \pm 0.49$ & $1.63 \pm 0.49$ & $0.39 \pm 0.09$ & $0.87 \pm 0.15^{\ddagger}$ & $0.83 \pm 0.27$ \\
\hline
\end{tabular}

Muscles were incubated with $50 \mathrm{nM}$ insulin for the indicated times, homogenized, and fractionated as described under Methods. Anti-p85- and antiPTyr-immunoprecipitable PI3K activity were assessed in the same muscle as described under Methods and in the legend to Fig. 1. Anti-p85 PI3K activity was expressed per milligram of total protein. AntiPTyr-PI3K activities in membranes and cytosol were expressed relative to the protein contents in the respective fractions. Results are presented as means $\pm \operatorname{SEM}(n=7-8)$. Significance between the lean and obese groups at each time point was established using Student's $t$ test. ${ }^{*} P<0.05$. ${ }^{\ddagger} P<0.025$.

that the insulin-resistant muscles were characterized by a $65 \%$ increase in basal receptor kinase activity, a $20 \%$ decrease in total kinase activity in the presence of $50 \mathrm{nM}$ insulin, and a $36 \%$ decrease in the insulin-specific stimulation (insulin minus basal) of the kinase. These data indicate that although obesityassociated skeletal muscle insulin resistance is clearly present at the level of the insulin receptor, the defect is not as prominent as that "downstream" at the level of PI3K.

Obesity-associated post-receptor defects. Since the diminution of skeletal muscle PI3K activation is greater than the alteration in insulin receptor tyrosine kinase activity in obese animals, one could suggest that post-receptor defects are present.

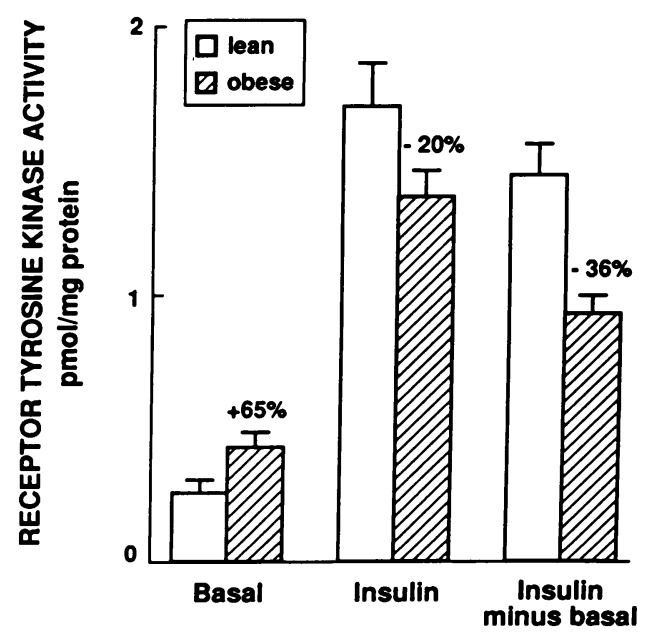

Figure 7. Insulin-stimulation of insulin receptor tyrosine kinase activity in soleus muscle from lean and obese mice. Solei were incubated for 10 min without and with $50 \mathrm{nM}$ insulin before being assayed for insulin receptor tyrosine kinase activity as described in Fig. 4. Values are expressed as means $\pm \operatorname{SEM}(n=8)$. Values for insulin minus basal were calculated from paired muscles, i.e., the muscle from one leg was incubated with insulin and that from the contralateral leg was incubated without insulin.
To address this question, we tested the ability of a preparation of native insulin receptors to associate with cytosolic PI3K in vitro. Immunopurified human insulin receptors were activated by phosphorylation, incubated with muscle cytosol, and the receptor-associated PI3K activity was determined. As seen in Table III, prior phosphorylation of the purified receptors resulted in a fourfold increase in the amount of receptor-associated PI3K. Moreover, this insulin-stimulated PI3K association was reduced by $40 \%$ in cytosol from obese animals. An apparent decrease in the basal PI3K activation of the same magnitude was also observed.

Reversal of obesity-associated defects in PI3K and insulin receptor tyrosine kinase by starvation. It is well established that a number of biochemical and hormonal abnormalities associated with insulin resistance in obese mice are normalized after $40 \mathrm{~h}$ of starvation (18). We thus examined the effect of starvation on PI3K and insulin receptor tyrosine kinase activi-

Table III. Activation of PI3K In Vitro by Native Human Insulin Receptors

\begin{tabular}{lcc}
\hline & \multicolumn{2}{c}{ PI3K activity associated with } \\
& receptors \\
\cline { 2 - 3 } & Lean mice & Obese \\
\hline Inactive receptors & $23.0 \pm 5.2$ & $15.2 \pm 3.8$ \\
Active receptors & 100 & $64.6 \pm 9.4^{*}$ \\
\hline
\end{tabular}

Muscles from lean or obese mice were preincubated, homogenized, and solubilized as in Fig. 1. After a brief centrifugation, the supernatant was incubated for $5 \mathrm{~min}$ at room temperature with activated or nonactivated insulin receptors. PI3K activity associated with the receptors was then determined as described under Methods. The supernatant protein contents were equalized before incubation with insulin receptors. Results were expressed as the percentage of the values obtained when homogenates from lean mice were incubated with activated insulin receptors and presented as means \pm SEM $(n=11)$. $* P<0.05$ compared to activated lean group. 
ties in soleus muscles incubated in the absence and presence of $50 \mathrm{nM}$ insulin. As seen in Fig. 8, there was a striking reversal of the defective insulin-stimulation of those parameters. Starvation had the additional effects of normalizing the elevated basal insulin receptor tyrosine kinase activity in muscles from obese animals as well as inducing hypoinsulinemia and hypoglycemia (Table I).

\section{Discussion}

The present study describes an insulin-responsive antiPTyrPI3K in the incubated skeletal muscle. The kinetics of the PI3K response, an initial activation phase followed by a slower partial deactivation phase, were similar to the kinetics reported in cultured cells transfected with insulin receptors and adipocytes $(1,2,13,14)$. Although over the course of this study the fold stimulation of antiPTyr-PI3K by $50 \mathrm{nM}$ insulin in soleus muscles from lean mice varied from 3 to 10 , the relative timeand insulin concentration-dependent changes in activity were
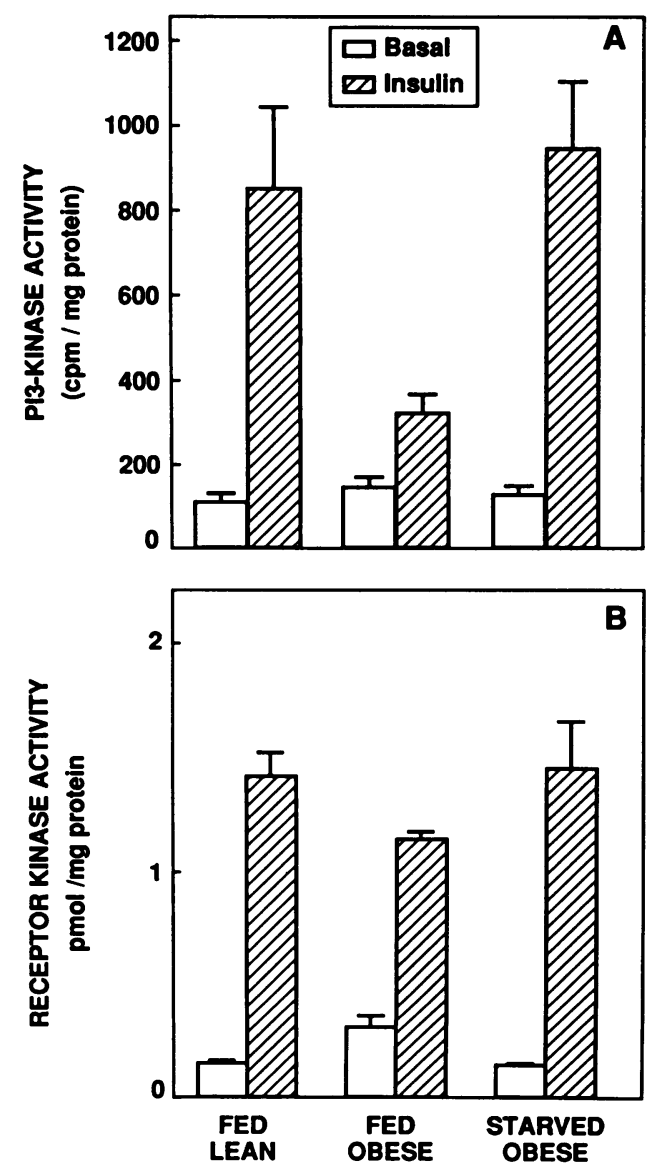

Figure 8. Effect of starvation on PI3K and insulin receptor tyrosine kinase activity in soleus muscles from obese mice. $(A)$ PI3K. Muscles were incubated in the presence or absence of $50 \mathrm{nM}$ insulin for 2 min before being assayed for antiPTyr-PI3K as described in the legend to Fig. 1. Results are presented as means $\pm \operatorname{SEM}(n=7-8)$. (B) IR tyrosine kinase. Muscles were incubated without and with $50 \mathrm{nM}$ insulin for $10 \mathrm{~min}$ before being assayed for receptor kinase activity as described in the legend to Fig. 4. Results are expressed as means $\pm \operatorname{SEM}(n=3-4)$. very reproducible; thus it is likely that differences in fold stimulation merely reflect fluctuations in basal activity. Due to the complex kinetics, it was not possible to "accurately" determine an $\mathrm{ED}_{50}$ for insulin's stimulation of PI3K; however, it is clear that insulin levels in the $1-10 \mathrm{nM}$ range provoke a significant PI3K activation. This places the sensitivity of PI3K to insulin close to physiological plasma insulin values (see Table I). Since insulin levels in this range also produced significant stimulations of glucose transport and the receptor tyrosine kinase (see Fig. 5), activation of antiPTyr-PI3K appears to be physiologically relevant.

Most available evidence suggests that PI3K activation by insulin occurs as a result of an interaction of the $85-\mathrm{kD}$ subunit with tyrosine phosphorylated IRS-1 (10-12) rather than by direct tyrosine phosphorylation (28). In adipocytes, this activation process appears to result in the translocation of PI3K from a cytosolic to a membrane compartment, with a subsequent increase in PI3K specific activity (14). In contrast, both the total PI3K activity and the membrane-associated fraction remained relatively constant following the insulin-stimulation of skeletal muscle (Table II). Although antiPTyr-immunoprecipitable activity in the particulate fraction was stimulated three to fourfold, we were unable to determine if it represents the activation of PI3K that was already membrane-associated or a genuine translocation. We can, however, conclude that $(a)$ antiPTyr-PI3K activity is enriched in the particulate fraction and $(b)$ if translocation of PI3K and/or an increase in its specific activity occur in skeletal muscle, they involve only a very small fraction of the total.

A comparison of the time course of soleus muscle PI3K stimulation by $50 \mathrm{nM}$ insulin with that of insulin receptor autophosphorylation and kinase activation reveals that PI3K activity peaks within 2-5 min while receptor kinase activity and autophosphorylation do not peak until after $30 \mathrm{~min}$. This time course of receptor tyrosine kinase activation is similar to that observed after insulin-injection in vivo in rat hindlimb muscle (29), but dissimilar to that reported in vivo in rat hindlimb muscle (30), where peak activity was observed at 2-5 min. The cause of these differing time courses is not known, but it could be related to technical differences between the various protocols for insulin stimulation in vivo as well as to the fact that in vivo stimulation is blunted by systemic counterregulatory factors whereas that in the isolated muscle is not. Our results would suggest that only a small fraction of the total receptor pool needs to be activated to induce a maximal PI3K stimulation. How PI3K is subsequently deactivated is not known, although it is reasonable to propose that there would be the stimulation of an "off switch" further downstream in the insulin signaling pathway, such as a substrate specific tyrosine phosphatase (31) or a serine/threonine kinase. In relation to the latter possibility, it is known that both IRS-1 and the $85-\mathrm{kD}$ PI3K regulatory subunit have multiple potential ser/thr phosphorylation sites $(10,32-35)$.

The blunted insulin-stimulation of antiPTyr-PI3K in muscles from obese animals demonstı ates that there is a defect very early in the post-receptor signaling pathway. This defect, which is equally observable in the cytosolic and particulate fractions, is characterized by decreases in both PI3K insulin response and sensitivity. Mechanistically, it appears to result from both insulin receptor and postreceptor defects since $(a)$ the decrease in PI3K activation was consistently more pronounced than that in tyrosine kinase activation and $(b)$ the activation of PI3K in 
vitro by native insulin receptors was diminished in homogenates from obese mice. While the diminished receptor kinase response is related to an alteration in the intrinsic receptor kinase activation ( receptor number was not affected by obesity in these experiments), the nature of the post-receptor defect(s) is less clear. Based on our data and present knowledge of the mechanism of PI3K activation by insulin, we would suggest that there is an alteration in the association of PI3K with IRS-1. Obesity clearly does not cause a decrease in total (anti-p85) PI3K activity. This does not exclude, however, an alteration in the PI3K per se, for example at the site with which it interacts with IRS-1. A more likely site for the defect is IRS-1. Indeed, hyperinsulinemia has been demonstrated to down-regulate IRS- 1 in cultured cells (36). Moreover, an apparent post receptor alteration in IRS-1 phosphorylation has recently been demonstrated in insulin-resistant skeletal muscle from streptozotocin diabetic rats (30); in this study there was a dissociation between IRS-1 tyrosine phosphorylation and insulin receptor autophosphorylation.

The insulin-resistant obese state is associated with a number of abnormalities, including elevated plasma lipids and insulin as well as a reduction in the biological effectiveness of insulin in its target tissues. Taken together, our observations imply that the defects leading to PI3K insulin resistance are interrelated with, if not the same as, those leading to insulin resistance in other biochemical pathways. Because several reports have suggested that hyperinsulinemia is the primary contributing factor to the insulin resistance associated with obesity and NIDDM (reviewed in reference 37), it is reasonable to speculate that hyperinsulinemia also plays a key role in the generation of the obesity-associated defects in PI3K activation. Supporting this hypothesis is the observation that starvation suppressed hyperinsulinemia while at the same time normalizing insulin receptor and postreceptor defects. It is notable that there was a strong correlation in obese mice between elevated plasma insulin and increased insulin receptor tyrosine kinase activity in solei incubated without insulin. This result was not observed in previous studies using the same animal model (19) which were less concerned with preserving the phosphorylation state of the insulin receptor. Because we observed no corresponding alteration in basal PI3K activity, the increase in basal receptor kinase activity is most likely offset by the post-receptor defect in the PI3K activation pathway.

The role of PI3K in cell physiology is still a mystery. While PI3K has been implicated in the regulation of cell growth, the presence of insulin-sensitive PI3K in terminally differentiated insulin-target tissues such as skeletal muscle and fat indicates that PI3K could have an equally important role in the regulation of metabolism. The blunted stimulation of PI3K by insulin in soleus muscles from obese mice suggests that its putative regulatory role would be related to processes such as glucose transport and metabolism that are insulin resistant in this tissue. In contrast, the present results do not support a rate-limiting role for PI3K in the regulation of protein metabolism since this process appears to be unaffected by GTG-induced obesity (38). The products of the PI3K reaction, PI3P, PI-3,4- $\mathrm{P}_{2}$, and $\mathrm{PI}-3,4,5-\mathrm{P}_{3}$, are not substrates for any known phospholipase $\mathrm{C}$ and thus would not contribute to signaling by the classical calcium protein kinase $C$ pathway (39). Therefore one must propose that the 3-phosphorylated phosphoinositides would exert their potential regulatory role at or near the membrane. The ability to explore more specifically the function of PI3K awaits the availability of large quantities of highly purified 3-phosphorylated phosphoinositides.

\section{Acknowledgments}

We thank C. Olichon-Berthe, H. Low, and R. Ballotti for critical reading of the manuscript. We thank R. Ballotti and S. Hauguel De Mouzon for the preparation of the antiphosphotyrosine antibody, and $\mathrm{A}$. Grima and G. Visciano for illustration work. Dr. Heydrick (Poste vert) and Dr. Jullien (Poste d'accueil) received support from INSERM. Dr. Heydrick thanks K. S. Chen for the protocol for the PI3-kinase assay.

This work was supported by grants from the Institut National de la Santé et de la Recherche Médicale (France), the Région Provence Côte d'Azur, the French Association for the Study of Myopathy, Servier Pharmaceuticals and by a research contract from Alfediam-Lilly (France).

\section{References}

1. Ruderman, N. B., R. Kapeller, M. F. White, and L. C. Cantley. 1990. Activation of phosphatidylinositol 3-kinase by insulin. Proc. Natl. Acad. Sci. USA. 87:1411-1415.

2. Endemann, G., K. Yonezawa, and R. A. Roth. 1990. Phosphatidylinositol kinase or an associated protein is a substrate for the insulin receptor tyrosine kinase. J. Biol. Chem. 265:396-400.

3. Carpenter, C. L., and L. C. Cantley. 1990. Phosphoinositide kinases. Biochemistry. 29:11147-11156.

4. Downes, C. P., and A. N. Carter. 1991. Phosphoinositide 3-kinase: a new effector in signal transduction. Cell. Signalling. 3:501-513.

5. Hiles, I. D., M. Otsu, S. Volinia, M. J. Fry, I. Goud, R. Dhand, G. Panayotou, F. Ruiz-Larrea, A. Thompson, N. F. Totty, et al. 1992. Phosphatidylinositol 3-kinase: structure and expression of the $110 \mathrm{kd}$ catalytic subunit. Cell. 70:419429.

6. Cantley, L. C., K. R. Auger, C. Carpenter, B. Duckworth, A. Graziani, R. Kapeller, and S. Soltoff. 1991. Oncogenes and signal transduction. Cell. 64:281302.

7. Backer, J. M., G. G. Schroeder, C. R. Kahn, M. G. J. Myers, P. A. Wilden, D. A. Cahill, and M. F. White. 1992. Insulin stimulation of phosphatidylinositol 3-kinase activity maps to insulin receptor regions required for endogenous substrate phosphorylation. J. Biol. Chem. 267:1367-1374.

8. Yonezawa, K., K. Yonoko, K. Shii, W. Ogawa, A. Ando, K. Hara, S. Baba, Y. Kaburagi, R. Yamamoto-Honda, K. Momomura, et al. 1992. In vitro association of phosphatidylinositol-3-kinase activity with the activated insulin receptor tyrosine kinase. J. Biol. Chem. 267:440-446.

9. Choudhury, G. G., L. M. Wang, J. Pierce, S. A. Harvey, and A. Y. Sakaguchi. 1991. A mutational analysis of phosphoinositol-3-kinase activation by human colony-stimulating factor-1 receptor. J. Biol. Chem. 266:8068-8072.

10. Sun, X. J., P. Rothenberg, C. R. Kahn, J. M. Backer, E. Araki, P. A. Wilden, D. A. Cahill, B. J. Goldstein and M. F. White. 1991. Structure of the insulin receptor substrate IRS-1 defines a unique signal transduction protein. Nature (Lond.) 352:73-77.

11. Backer, J. M., M. G. J. Myers, S. E. Shoelson, D. J. Chin, X.-J. Sun, M. Miralpeix, P. Hu, B. Margolis, Y. Skolnik, J. Schlessinger, et al. 1992. Phosphatidylinositol 3'-kinase is activated by association with IRS-1 during insulin stimulation. EMBO (Eur. Mol. Biol. Organ.) J. 11:3469-3479.

12. Hadari, Y. R., E. Tzahar, O. Nadiv, P. Rothenberg, C. T. Roberts, Jr., D. LeRoith, Y. Yarden, and Y. Zick. 1992. Insulin and insulinomimetic agents induce activation of phosphatidylinositol 3'-kinase upon its association with pp185 (IRS-1) in intact rat livers. J. Biol. Chem. 267:17483-17486.

13. Kelly, K. L., N. B. Ruderman, and K. S. Chen. 1992. Phosphatidylinositol-3-kinase in isolated rat adipocytes. J. Biol. Chem. 267:3423-3428.

14. Giorgetti, S., R. Ballotti, A. Kowalski-Chauvel, M. Cormont, and E. Van Obberghen. 1992. Insulin stimulates PI 3-kinase activity in rat adipocytes. Eur. J. Biochem. 207:599-606.

15. DeFronzo, R. A., R. Gunnarsson, O. Bjorkman, M. Olsson and J. Wahlen. 1985. Effects of insulin on peripheral and splanchnic glucose metabolism in noninsulin dependent (Type II) diabetes mellitus. J. Clin. Invest. 76:149-155.

16. Cahill, G. F. 1971. In Muscle Metabolism during Exercise. (B. Pernow, and B. Saltin, editors). Plenum Press, New York. 103-110.

17. Le Marchand, Y., P. Freychet, and B. Jeanrenaud. 1978. Longitudinal study on the establishment of insulin resistance in hypothalamic obese mice. Endocrinology. 102:74-85.

18. Le Marchand-Brustel, Y., B. Jeanrenaud, and P. Freychet. 1978. Insulin binding and effects in isolated soleus muscle of lean and obese mice. $\mathrm{Am}$. J. Physiol. 234:E348-E358. 
19. Le Marchand-Brustel, Y., T. Grémeaux, R. Ballotti and E. Van Obberghen. 1985. Insulin receptor tyrosine kinase is defective in skeletal muscle of insulin-resistant obese mice. Nature (Lond.). 315:676-679.

20. Le Marchand-Brustel, Y., N. Moutard, and P. Freychet. 1982. Aminoisobutyric acid transport in soleus muscles of lean and gold thioglucose-obese mice. Am. J. Physiol. 243:E74-E79.

21. Le Marchand-Brustel, Y., and P. Freychet. 1980. Alteration of glycogen synthase activation by insulin in soleus muscles of obese mice. FEBS (Fed. Eur. Biochem. Soc.) Lett. 120:205-208.

22. Ballotti, R., J. C. Scimeca, A. Kowalski, and E. Van Obberghen. 1989. Antiphosphotyrosine antibodies modulate insulin receptor kinase activity and insulin action. Cell. Signalling. 1:195-204.

23. Auger, K. R., L. A. Serunian, S. P. Soltoff, P. Libby, and L. C. Cantley. 1989. PDGF-dependent tyrosine phosphorylation stimulates production of novel polyphosphoinositides in intact cells. Cell. 57:167-175.

24. Whitman, M., C. P. Downes, T. Keeler, T. Keller, and L. C. Cantley. 1988. Type I phosphatidylinositol kinase makes a novel inositol phospholipid, phosphatidylinositol-3-phosphate. Nature (Lond.). 332:644-646.

25. Sultan, C., M. Breton, G. Mauco, P. Grondin, M. Plantavid, and H. Chap. 1990. The novel inositol lipid phosphatidylinositol 3,4-bisphosphate is produced by human blood platelets upon thrombin stimulation. Biochem. J. 269:831-834.

26. Tanti, J. F., T. Grémeaux, E. Van Obberghen, and Y. Le Marchand-Brustel. 1991. Effects of okadaic acid, an inhibitor of proteinphosphatases-1 and -2A, on glucose transport and metabolism in skeletal muscle. J. Biol. Chem. 266:2099-2103.

27. Giorgetti, S., R. Ballotti, A. Kowalski-Chauvel, S. Tartare, and E. Van Obberghen. 1993. The insulin and insulin-like growth factor-I receptor substrate IRS-1 associates with and activates phosphatiolylinositol 3-kinase in vitro. $J$. Biol. Chem. In press.

28. Hayashi, H., N. Miyake, F. Kanai, F. Shibasaki, T. Takenawa, and Y. Ebina. 1991. Phosphorylation in vitro of the $85 \mathrm{kDa}$ subunit of phosphatidylinositol 3-kinase and its possible activation by insulin receptor tyrosine kinase. Biochem. J. 280:769-775.

29. Burant, C. F., M. K. Treutelaar, and M. G. Buse. 1986. In vitro and in vivo activation of the insulin receptor kinase in control and denervated skeletal muscle. J. Biol. Chem. 261:8985-8993.
30. Giorgino, F., J. H. Chen, and R. J. Smith. 1992. Changes in tyrosine phosphorylation of insulin receptors and a 170,000 molecular weight nonreceptor protein in vivo in skeletal muscle of streptozotocin-induced diabetic rats: effects of insulin and glucose. Endocrinology. 130:1433-1444.

31. McGuire, M. C., R. M. Fields, B. L. Nyomba, I. Raz, C. Bogardus, N. K Tonks, and J. Sommercorn. 1991. Abnormal regulation of protein tyrosine phosphatase activities in skeletal muscle of insulin-resistant humans. Diabetes. 40:939-942.

32. Rothenberg, P. L., W. S. Lane, A. Karasik, J. Backer, M. White, and C. R. Kahn. 1991. Purification and partial sequence of pp185, the major cellular substrate of the insulin receptor tyrosine kinase. J. Biol. Chem. 266:8302-8311.

33. Otsu, M., I. Hiles, I. Gout, M. J. Fry, F. Ruiz-Larrea, G. Panayotou, A. Thompson, R. Dhand, J. Hsuan, N. Totty, et al. 1991. Characterization of two 85 kd proteins that associate with receptor tyrosine kinases, middle- $\mathrm{T} / \mathrm{pp} 60 \mathrm{c}$-src complexes, and PI3-Kinase. Cell. 65:91-104.

34. Escobedo, J. A., S. Navankasattusas, W. M. Kavanaugh, D. Milfay, V. A. Fried, and L. T. Williams. 1991. cDNA cloning of a novel $85 \mathrm{kd}$ protein that has $\mathrm{SH} 2$ domains and regulates binding of PI3-kinase to the PDGF $\beta$-receptor. Cell. 65:75-82.

35. Skolnik, E. Y., B. Margolis, M. Mohammadi, E. Lowenstein, R. Fischer, A. Drepps, A. Ullrich, and J. Schlessinger. 1991. Cloning of PI3-Kinase-associated p85 utilizing a novel method for expression/cloning of target proteins for receptor tyrosine kinases. Cell. 65:83-90.

36. Rice, K. M., G. E. Lienhard, and C. Garner. 1992. Regulation of the expression of pp160, a putative insulin receptor signal protein, by insulin, dexamethasone, and 1-methyl-3-isobutylxanthine in 3T3-L1 adipocytes. J. Biol. Chem. 267:10163-10167.

37. Jeanrenaud, B. 1979. Insulin and obesity. Diabetologia. 17:133-138.

38. Monier, S., A. Le Cam, and Y. Le Marchand-Brustel. 1983. Insulin and insulin-like growth factor I: Effects on protein synthesis in isolated muscles from lean and goldthioglucose-obese mice. Diabetes. 32:392-396.

39. Serunian, L. A., M. T. Haber, T. Fukui, J. W. Kim, S. G. Rhee, J. M. Lowenstein, and L. C. Cantley. 1989. Polyphosphoinositides produced by phosphatidylinositol 3-kinase are poor substrates for phospholipases $\mathrm{C}$ from rat liver and bovine brain. J. Biol. Chem. 264:17809-17815. 